\title{
USE OF NONRADIOACTIVE LABELING TO DETECT LARGE GENE REARRANGEMENTS IN 21- HYDROXYLASE DEFICIENCY
}

\author{
Priscilla Cukier, Tânia A. S. S. Bachega, Berenice B. Mendonça and Ana Elisa C.
} Billerbeck

CUKIER $\mathrm{P}$ et al. Use of nonradioactive labeling to detect large gene rearrangements in 21-hydroxylase deficiency. Rev.

Hosp. Clín. Fac. Med. S. Paulo 59(6):369-374, 2004.

PURPOSE: To establish the Southern blotting technique using hybridization with a nonradioactive probe to detect large rearrangements of CYP21A2 in a Brazilian cohort with congenital adrenal hyperplasia due to 21-hydroxylase deficiency (CAH-21OH).

METHOD: We studied 42 patients, 2 of them related, comprising 80 non-related alleles. DNA samples were obtained from peripheral blood, digested by restriction enzyme Taq I, submitted to Southern blotting and hybridized with biotinlabeled probes.

RESULTS: This method was shown to be reliable with results similar to the radioactive-labeling method. We found CYP21A2 deletion (2.5\%), large gene conversion (8.8\%), CYP21AP deletion (3.8\%), and CYP21A1P duplication (6.3\%). These frequencies were similar to those found in our previous study in which a large number of cases were studied. Good hybridization patterns were achieved with a smaller amount of DNA $(5 \mu \mathrm{g})$, and fragment signs were observed after 5 minutes to 1 hour of exposure.

CONCLUSIONS: We established a non-radioactive (biotin) Southern blot/hybridization methodology for CYP21A2 large rearrangements with good results. Despite being more arduous, this technique is faster, requires a smaller amount of DNA, and most importantly, avoids problems with the use of radioactivity.

KEYWORDS: Biotin labeling. Large rearrangements. Southern blotting. CAH-21OH.

Congenital adrenal hyperplasia $(\mathrm{CAH})$ due to 21-hydroxylase deficiency (21OHD) is one of the most frequently inherited metabolism disorders. The impairment of $210 \mathrm{H}$ activity decreases cortisol synthesis, resulting in chronic stimulation of the adrenal cortex by adrenocorticotrophic hormone with consequent adrenal hyperplasia, leading to accumulation of steroid precursors, including androgens, causing virilization.

Congenital adrenal hyperplasia due to 21-hydroxylase deficiency is traditionally divided into classical and non-classical forms. The classical form is divided into salt-wasting ( $\mathrm{SW}$ ) and simple virilizing (SV) forms. ${ }^{1}$ In the classical form, virilization begins prenatally and females present ambiguous genitalia at birth, virilization continues postnatally in both sexes causing enlargement of the clitoris or penis, precocious pubarche and advance of bone maturation resulting in reduced final height. ${ }^{2}$ In about two-

From the Discipline od Endocrinology, Hospital das Clínicas, Faculty of Medicine, University of São Paulo - São Paulo/SP, Brazil.

E-mail: aecbil@usp.br

Received for publication on March 22, 2004 Accepted for publication on May 31, 2004. thirds of the cases, a severe mineralocorticoid deficiency develops, leading to the inability to conserve urinary sodium (SW form) causing dehydration with hyponatremia and hyperkalemia at first weeks after birth. ${ }^{3}$ In the nonclassical form (NC), symptoms of androgen excess, such as precocious pubarche, menstrual abnormalities, acne, hirsutism, and infertility, when present, appear during childhood, puberty, or adult life. The different clinical forms are due to different degrees of enzyme activity caused by mutations present in the gene that codifies 21-hydroxylase, the CYP21A2 gene. $^{4}$ 
The CYP21A2 gene and its pseudogene CYP21A1P are located 30 $\mathrm{kb}$ from each other on the short arm of chromosome 6 (6p21.3), within the locus that codifies the human leukocyte antigen (HLA) complex class III, adjacent to and alternating with the $C 4 A$ and $C 4 B$ genes, which encode the fourth component of complement.

Both genes contain 10 exons and present high homology $(98 \%$ in the exon sequences). The gene adjacent to $C 4 A$ is the pseudogene that has several mutations and therefore does not produce a protein, and the gene adjacent to $C 4 B$ is the active gene that codifies a protein with 494 amino acids. ${ }^{5,6}$

This region of chromosome 6 has at least 5 pairs of duplicated genes with high levels of nucleotide identity. This homology predisposes unequal pairing during meiosis, leading to unequal crossing-over between the active gene and its pseudogene, causing deletions, duplications, and transference of deleterious sequences from the CYP21A1P gene to CYP21A2 (large and microconversions). ${ }^{7,8}$

Usually, the large mutations are detected by Southern blot techniques followed by hybridization with a radioactive probe, while the point mutations are studied by allele-specific polymerase chain reaction (PCR),, 10 direct sequencing of PCR products, ${ }^{11}$ allele-specific hybridization (ASO), ${ }^{11-}$ ${ }^{14}$ or ligase detection reactions. ${ }^{15,16}$ The frequency of large mutations varies from $11 \%$ to $33 \%$ of the alleles of individuals with $\mathrm{CAH}$ 21-OHD and occurs mainly in the classical form in different populations. ${ }^{17-22}$

The Southern blot method normally requires the use of radioactive material, usually ${ }^{32} \mathrm{P}$, to label probes. The majority of the studies analyzing large rearrangements in $\mathrm{CAH}$ 21-OHD patients use this material. ${ }^{32} \mathrm{P}$ is highly hazardous, and the laboratory needs a license and trained personal to work with this material.
Our aim was to establish the use of nonradioactive labeling with the Southern blot methodology, studying 42 patients with different clinical forms of CAH-21-OHD.

Nonradioactive labeling has already been used in other studies with other genes. ${ }^{23,24}$

\section{PATIENTS}

All families gave their informed consent for the genetic study.

We studied 42 patients with CAH$21 \mathrm{OH}, 5$ genetically males and 37 females; 9 had the SV form, 11 had the SW form, and 22 had the NC form. These patients belong to 41 families, 2 of them related. One family reported first-degree consanguinity and there were 2 affected sons in another family. The parents, when available, were also studied in order to segregate the mutations. Therefore, we studied 80 nonrelated alleles, 16 of the SV form, 21 of the SW form, and 43 of the NC form.

The SV form was diagnosed when ambiguous genitalia was seen at birth in females and isosexual precocious puberty in males. In the SW form, in addition to the virilization signals, the patients also presented a history of salt-wasting crises during the first weeks of life. In the classical form, the basal levels of 17-hydroxyprogesterone were $>60 \mathrm{ng} / \mathrm{mL}$. The patients with the $\mathrm{NC}$ form presented precocious pubarche, primary or secondary amenorrhea, hirsutism, and 17hydroxyprogesterone levels after ACTH stimulation $>10 \mathrm{ng} / \mathrm{mL}^{25}$

\section{METHODS}

DNA samples from patients and their relatives were obtained from peripheral blood by the proteinase $\mathrm{K}$ phenol/chloroform method ${ }^{26}$ and stocked in TE 10:1 (Tris- $\mathrm{HCl} 10 \mathrm{mM}$, pH 7.5 ; EDTA $1 \mathrm{mM} \mathrm{pH} 8.0$ ) at $4^{\circ} \mathrm{C}$.

Six micrograms of genomic DNA was digested with the Taq I (Invitrogen) restriction enzyme, with a concentration of $5 \mu \mathrm{g}$ DNA, according to the manufacturer's instructions. The digested DNA was submitted to electrophoresis for 36 hours at $40 \mathrm{~V}$. After 36 hours, the DNA was transferred from the gel to nylon membranes by capillarity using a 10x SSC solution (20x $\mathrm{SSC}=3 \mathrm{M}$ sodium chloride, $0.3 \mathrm{M}$ sodium citrate) and was fixed in the membrane by incubation for 1 hour at $80^{\circ} \mathrm{C}$.

The probes were labeled with biotin-14-dCTP by random priming, using the manufacturer's instructions (Bioprime DNA Labeling Gibco$\mathrm{BRL}$ ). In brief, $200 \mathrm{ng}$ of probe together with a random primer solution were denatured by boiling for $5 \mathrm{~min}$ utes and cooled in ice. A dNTP mixture and $40 \mathrm{UI}$ of Klenow enzyme were added, and the solution was maintained at $37^{\circ} \mathrm{C}$ for 3 hours. After that, the reaction was stopped and the unincorporated nucleotides were separated from the probe through a Sephadex G50 column.

Pre-hybridization, hybridization, and detection of the labeled probe were performed according to the manufacturer's instructions. Pre-hybridization and hybridization were performed at $42^{\circ} \mathrm{C}$ in $5 \mathrm{xSSPE}, 0.1 \%$ Denhardt's solution, $5 \%$ dextran sulfate, $1 \%$ SDS, $0.2 \mathrm{mg} / \mathrm{mL}$ denatured salmon sperm DNA and 50\% formamide solution. The pre-hybridization was carried out for 4 hours while hybridization took 24 hours. After hybridization, membranes were submitted to stringent washes $\left(65^{\circ} \mathrm{C}\right.$ and $\left.50^{\circ} \mathrm{C}\right)$, and the streptavidine-alkaline-phosphatase conjugate was bonded to the hybridized biotinylated probe. The chemiluminescent detection was done with the Photogene Nucleic Acid Detection System version 2.0 kit (Gibco- 
BRL). The membrane was incubated with an alkaline phosphatase substrate (LUMI-PHOS) that emits light when dephosphorylated and exposed to Xray films. This procedure was performed to determine the number of copies of $C Y P 21$ genes. The number of copies of a fragment was determined comparing the signal intensity of both CYP21 genes in the same electrophoretic lane. The fragments of 3.7 and $2.5 \mathrm{kB}$ correspond to the CYP21A2 gene and the fragments of 3.2 and 2.4 $\mathrm{kB}$ to the CYP21A1P gene. For a precise molecular diagnosis, as in the radioactive labeling methodology, a densitometric analysis to compare the intensity of the signal of the bands would be necessary, although results with and without densitometry were very similar.

\section{RESULTS}

Hybridization patterns of the samples obtained with the biotinylated probe are shown in Figure 1. The first column shows the lack of the $3.7 \mathrm{kB}$ band and the presence of the 3.2, 2.5 and $2.4 \mathrm{kB}$ bands with same intensity of signal, indicating a homozygous large gene conversion. The third and fourteenth columns show a decreased signal in the 3.2 and $2.4 \mathrm{kB}$ bands when compared respectively to the 3.7 and $2.5 \mathrm{kB}$ bands, indicating a heterozygous CYP21A1P deletion. In the fourth column, there is a heterozygous gene conversion because of decreased signal of the $3.7 \mathrm{kB}$ band compared to the $3.2 \mathrm{kB}, 2.4$, and $2.5 \mathrm{kB}$ bands with same intensity of signal. The fifth to twelfth columns represent normal hybridization patterns. For a better understanding of the results, Figure 2 shows the Taq I restriction sites in CYP21A2 and its pseudogene.

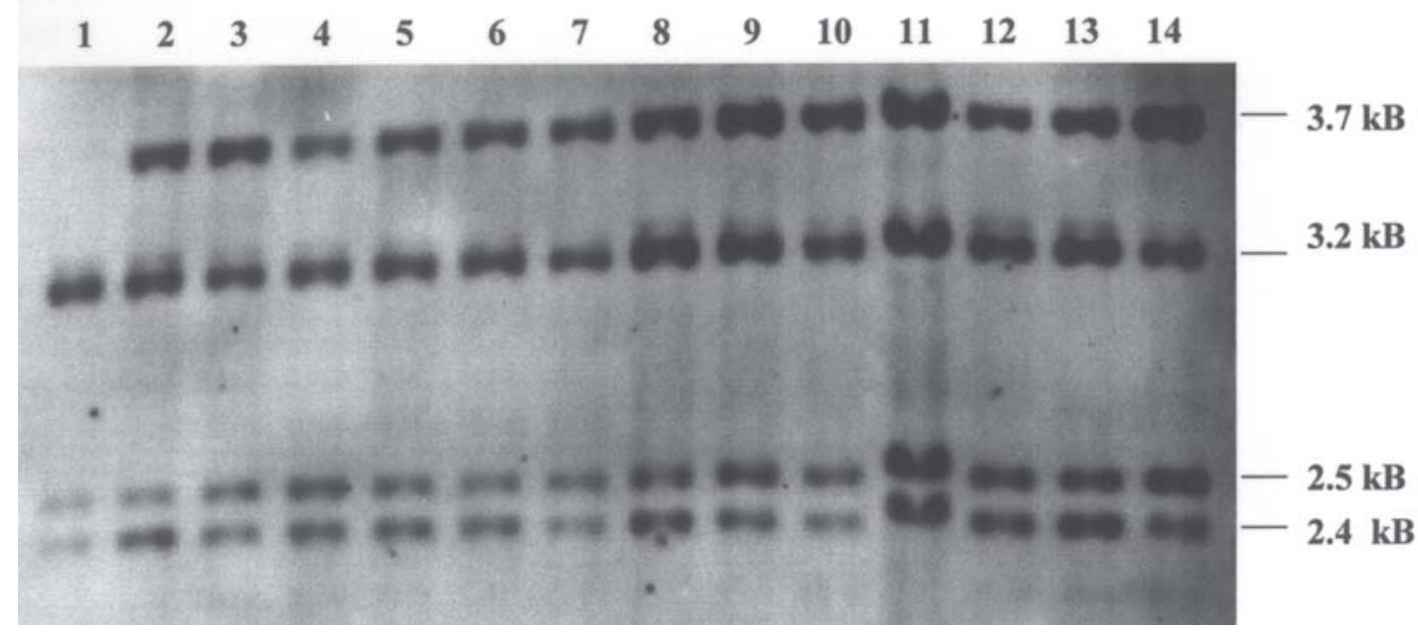

Figure 1 - Hybridization pattern of the biotinylated CYP21A2 probe to genomic DNA digested by Taq I restriction enzyme. Lane 1 homozygous gene conversion; lanes 2 and 13, heterozygous CYP21A1P duplication; lanes 3 and 14, heterozygous CYP21A1P deletion; lane 4, heterozygous gene conversion; lanes 5 to 12 , normal hybridization pattern.

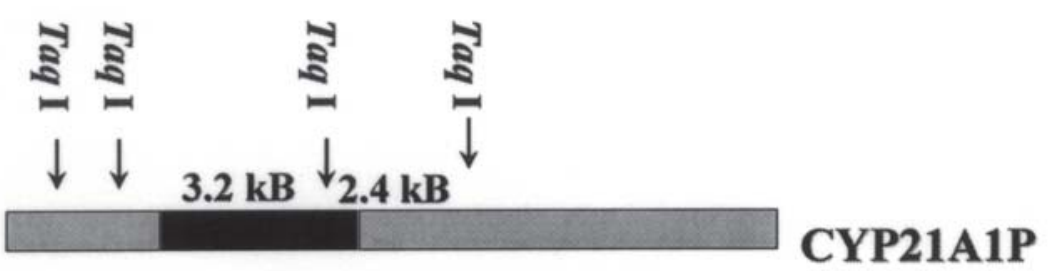

Genomic probe of CYP21

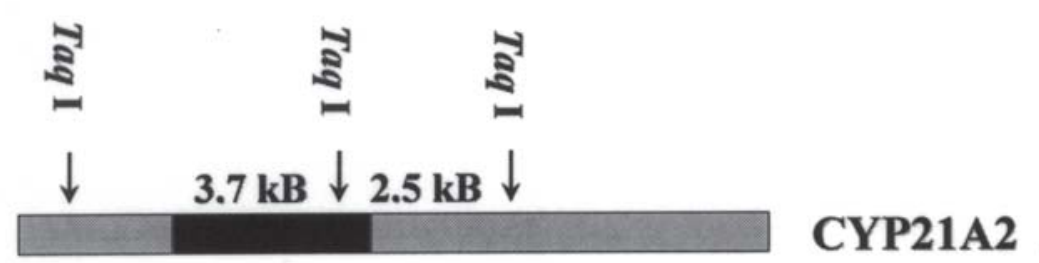

Figure 2 - Representation of Taq I restriction sites of CYP21A1P and CYP21A2 genes. Fragments of 3,2 and 2,4 kB are from the pseudogene (CYP21A1P) and fragments of 3,7 and 2,5 kB are from the active gene (CYP21A2). 
Analyzing these 80 unrelated alleles, we found that $78.6 \%$ of the alleles presented a normal hybridization pattern, $2.5 \%$ a $C Y P 21 A 2$ deletion pattern, $8.8 \%$ a large gene conversion, and $3.8 \%$ and $6.3 \%$ presented CYP21A1P deletion and duplication patterns, respectively. As expected, the CYP21A2 deletion and the large gene conversion occurred only in the SW form, and the CYP21A1P duplication was observed mainly in the non-classical form, CYP21A2 duplication was not found.

\section{DISCUSSION}

The main purpose of this work was establish in our service the screening of large mutations with a nonradiolabelling methodology, since radioactive reagents are harder to obtain, have a short half life, are dangerous when used by people who are not well trained to handle them, and produce hazardous waste materials that require special facilities for long-term storage.
We observed that biotin labeling emits a signal equivalent in intensity to that of radioactive labeling. Another advantage of this method is that due to its greater sensitivity, smaller amounts of DNA are needed (2 - $5 \mu \mathrm{g}$ compared to $10 \mu \mathrm{g}$ when ${ }^{32} \mathrm{P}$ is used). Sometimes large amounts of DNA are not available. The smaller amount of DNA needed and the shorter time required for exposure to X-ray films make this procedure more effective for use in prenatal diagnosis of large gene rearrangements in families with a history of CAH 21-OHD.

In this study we found a low incidence of large rearrangements involving CYP21A2 in our sample (10.3\% of non-related-alleles). CYP21A2 deletions were seen only in the SW form, and large gene conversions were observed in the $\mathrm{NC}(4.7 \%)$ and $\mathrm{SW}$ (23.8\%) forms. The CYP21AIP rearrangements are not mutations causing disease but can be associated with CYP21A2 point mutations. The frequency of large rearrangement mutations in this sample was similar to that found in a previous population study in a Brazilian sample performed by our group with different patients comprising a large number of cases. ${ }^{21}$ For comparison of both methodologies, some of the patients included in this study with biotin labeling had a previous molecular diagnosis by a radiolabeling methodology, with similar results.

In conclusion, the nonradioactive (biotin) labeling, although more arduous, allowed accurate molecular diagnosis of large gene rearrangements in patients with $\mathrm{CAH}$ 21-OHD with the advantages of the use of a small amount of DNA and avoiding the use of hazardous radioactive material. This technique proved to be a good alternative for routine use.

\section{ACKNOWLEDGEMENTS}

We thank FAPESP that partially supported this work with a grant (95/ 8325-6) and supported TASSB (95/ 8325-6) and PC (98/03731-4).

\section{RESUMO}

CUKIER P e col. Uso de marcação não radiativa para identificação de grandes rearranjos gênicos na deficiência da 21-hidroxilase. Rev. Hosp. Clín. Fac. Med. S. Paulo 59(6):369-374, 2004.

OBJETIVO: Padronizar a técnica de Southern blotting usando hibridização com material não radioativo para detectar grandes rearranjos no gene CYP21A2 em uma amostra da população brasileira com hiperplasia adrenal congênita.
MÉTODO: Foram estudados 42 pacientes, 2 dos quais aparentados, totalizando 80 alelos não relacionados. As amostras de DNA foram obtidas de sangue periférico, digeridas com enzima de restrição Taq I, realizado Southern blotting e hibridizadas com sonda marcada com biotina.

RESULTADOS: O método se mostrou eficaz, com resultados similares aos encontrados ao utilizar a metodologia com material radioativo. Foram encontradas $2,5 \%$ de deleção do CYP21A2, 8,8\% de grandes conver- sões, $3,8 \%$ de deleção do CYP21A1P e 6,3\% de duplicação do CYP21A1P. Estas freqüências foram similares às encontradas em nosso estudo prévio, onde um número significante de casos foi estudado. Um bom padrão de hibridização foi alcançado utilizando menor quantidade de DNA (5mg) e a emissão de sinais foi observada entre 5 minutos e 1 hora de exposição.

CONCLUSÕES: Padronizamos uma técnica de Southern blotting/ hibridização com material não radioativo (biotina) para a pesquisa de gran- 
des rearranjos no gene CYP21A2 com bons resultados. Apesar de ser mais trabalhoso, este método é mais rápido, utiliza menores quantidades de DNA e, principalmente, evita problemas com o uso de radioatividade.
UNITERMOS: Biotina. Grandes rearranjos. Southern blotting. CAH$210 H$.

\section{REFERENCES}

1. New MI, White PC, Pang S, Dupont B, Speiser PW. The adrenal hyperplasias. In: Sriver CR, Beaudet AL, Sly S, Valle D, editors. The Metabolic Basis of Inherited Diseases. 6th ed. New York: Mc Graw-Hill; 1989. p.1881-917.

2. Miller WL. Clinical review 54: Genetics, diagnosis, and management of 21-hydroxylase deficiency. J Clin Endocrinol Metab 1994;78:241-6.

3. Strachan T. Molecular pathology of congenital adrenal hyperplasia. Clin Endocrinol 1990 Mar;32:373-93.

4. Miller WL, Levine LS . Molecular and clinical advances in congenital adrenal hyperplasia. J Pediatr 1987;111:1-17.

5. White PC, New MI, Dupont B. Structure of human steroid 21hydroxylase genes. Proc Natl Acad Sci USA 1986;83:5111-5.

6. Higashi Y, Yoshioka H, Yamane M, Gotoh O, Fujii-Kuriyama Y. Complete nucleotide sequence of two steroid 21-hydroxylase genes tandemly arranged in human chromosome: a pseudogene and a genuine gene. Proc Natl Acad Sci USA 1986;83:28415 .

7. White PC, New MI, Dupont B. HLA-linked congenital adrenal hyperplasia results from a defective gene encoding a cytochrome P-450 specific for steroid 21-hydroxylation. Proc Natl Acad Sci USA 1984;81:7505-9.

8. Miller WL. Congenital lipoid adrenal hyperplasia: the human gene knockout for the steroidogenic acute regulatory protein. J Mol Endocrinol 1997;19:227-40.

9. Wilson RC, Wei JQ, Cheng KC, Mercado AB, New MI. Rapid deoxyribonucleic acid analysis by allele-specific polymerase chain reaction for detection of mutations in the steroid 21hydroxylase gene. J Clin Endocrinol Metab 1995;80:163540 .

10. Wedell A, Luthman H. Steroid 21-hydroxylase deficiency: two additional mutations in salt-wasting disease and rapid screening of disease-causing mutations. Hum Mol Genet 1993;2:499504.

11. Carrera P, Bordone L, Azzani T, Brunelli V, Garancini MP, Chiumello G, Ferrari M. Point mutations in Italian patients with classic, non-classic, and cryptic forms of steroid 21hydroxylase deficiency. Hum Genet 1996;98:662-5.
12. Mornet E, Crete P, Kuttenn F, Raux-Demay MC, Boue J, White $\mathrm{PC}$, Boue A. Distribution of deletions and seven point mutations on CYP21B genes in three clinical forms of steroid 21hydroxylase deficiency. Am J Hum Genet 1991;48:79-88.

13. Ezquieta B, Oliver A, Gracia R, Gancedo PG. Analysis of steroid 21-hydroxylase gene mutations in the Spanish population. Hum Genet 1995;96:198-204.

14. Dardis A, Bergada I, Bergada C, Rivarola M, Belgorosky A. Mutations of the steroid 21-hydroxylase gene in an Argentinian population of 36 patients with classical congenital adrenal hyperplasia. J Pediatr Endocrinol Metab 1997;10:55-61.

15. Day DJ, Speiser PW, Schulze E, Bettendorf M, Fitness J, Barany F, White PC. Identification of non-amplifying CYP21 genes when using PCR-based diagnosis of 21-hydroxylase deficiency in congenital adrenal hyperplasia $(\mathrm{CAH})$ affected pedigrees. Hum Mol Genet 1996;5:2039-48.

16. Chin D, Speiser PW, Imperato-McGinley J, Dixit N, Uli N, David R, Oberfield SE. Study of a kindred with classic congenital adrenal hyperplasia: diagnostic challenge due to phenotypic variance. Clin Endocrinol Metab 1998;83:1940-5.

17. Speiser PW, Dupont J, Zhu D, Serrat J, Buegeleisen M, TusieLuna MT, et al. Disease expression and molecular genotype in congenital adrenal hyperplasia due to 21-hydroxylase deficiency. J Clin Invest 1992;90:584-95.

18. Carrera P, Ferrari M, Beccaro F, Spiga I, Zanussi M, Rigon F, et al. Molecular characterization of 21-hydroxylase deficiency in 70 Italian families. Hum Hered 1993;43:190-6.

19. Wedell A, Thilen A, Ritzen EM, Stengler B, Luthman H. Mutational spectrum of the steroid 21-hydroxilase gene in Sweden: implications for genetic diagnosis and association with disease manifestation. J Clin Endocrinol Metab 1994;78:1145-52.

20. Ezquieta B, Varela JM, Jariego C, Oliver A, Gracia R. Nonisotopic detection of point mutations in CYP21B gene in steroid 21hydroxylase deficiency. Clin Chem 1996;42:1108-10.

21. Bachega TA, Billerbeck AC, Madureira G, Arnhold IJ, Medeiros MA, Marcondes JA, et al. Low frequency of CYP21B deletions in Brazilian patients with congenital adrenal hyperplasia due to 21-hydroxylase deficiency. Hum Hered 1999;49:9-14. 
22. Baumgartner-Parzer SM, Schulze E, Waldhausl W, Pauschenwein S, Rondot S, Nowotny P, et al. Mutational spectrum of the steroid 21-hydroxylase gene in Austria: identification of a novel missense mutation. J Clin Endocrinol Metab 2001;86:4771-5.

23. Rihn B, Coulais C, Bottin MC, Martinet N. Evaluation of nonradioactive Labeling and detection of deoxyribonucleic acids. Part One: Chemiluminescent methods. J Biochem Biophys Methods 1995;30:91-102.
24. Mansfield ES, Worley JM, McKenzie SE, Surrey S, Rappaport E, Fortina P. Nucleic acid detection using non-radioactive labelling methods. Mol Cell Probes 1995;9:145-56.

25. New MI, Lorenzen F, Lerner AJ, Kohn B, Oberfield SE, Pollack MS, et al. Genotyping steroid 21-hydroxylase deficiency: hormonal reference data. J Clin Endocrinol Metab $1983 ; 57: 320-6$.

26. Sambrook J, Fritsh EF, Maniatis T. Molecular cloning. A laboratory manual. $2^{\text {nd }}$ ed. Cold Spring: Harbor Laboratory Press; 1989. 